\title{
Estimation of a German money demand system - a long-run analysis
}

\author{
Kirstin Hubrich* \\ Institut fur Statistik und Ökonometrie, Humboldt-Universität zu Berlin, Spandauer Str.1, \\ D-10178 Berlin, Germany (e-mail: kirstin@wiwi.hu-berlin.de)
}

First version received: October 1996/final version received: July 1997

\begin{abstract}
This study presents a multivariate analysis of the stability of longrun relationships between variables that influence the conduct and transmission process of the German monetary policy. The initial VAR comprises the variables real money $\mathrm{M} 3$, real GNP, the inflation rate, a long-term and a weighted short-term interest rate. A multivariate approach has been chosen, as this allows for more than one cointegration relationship and to test restrictions on the cointegration space. In contrast to most other studies on German monetary policy, three stable and economically plausible cointegration relationships are obtained simultaneously within the framework of the Johansen procedure: a money demand relationship, a long-run Fisher effect and a long-run relationship between the short- and the long-term interest rate. It is apparent that the structural break of German reunification can be modelled incorporating dummy variables in the model.
\end{abstract}

Key words: Money demand, Fisher effect, interest rate spread, German monetary policy, Johansen procedure

JEL classifications: E41, E43, C32, C51, C52

\footnotetext{
* I would like to thank Helmut Lütkepohl, Jürgen Wolters and Jörg Breitung for many valuable comments and discussions. I am also grateful to Neil Ericsson, Stefano Fachin, Katarina Juselius, Jürgen Kromphardt, Dieter Nautz, Pentti Saikkonen, Timo Teräsvirta, Katrin Wesche, Carlo Winder, participants of the ESEM96 (Istanbul), two anonymous referees and the editor for helfpul comments and suggestions. Responsibility for any remaining errors is, however, mine alone. The research for this paper was carried out within the Sonderforschungbereich 373 at Humboldt University. Financial support of the Deutsche Forschungsgemeinschaft is gratefully acknowledged.
} 


\section{Introduction}

The empirical analysis presented in this study is based on the concept of cointegration. In contrast to most earlier research on German monetary policy, this analysis is carried out within a multivariate framework, extensively testing restrictions on cointegration vectors. The Johansen procedure is applied, as the aim is to simultaneously test for stable long-run relationships that influence the conduct and transmission process of German monetary policy. One important precondition for the policy of monetary targeting by the Deutsche Bundesbank (henceforth: Bundesbank) is the stability of German money demand for a period including German reunification. In addition to the money demand relationship, the long-run spread between short- and long-term interest rates and the long-run Fisher equation are tested. Apart from its monetary target M3, the Bundesbank monitors a number of economic variables in the financial as well as the real sector. ${ }^{1}$ The term structure plays an important role in the context of German monetary policy since it serves the Bundesbank as an indicator for inflationary expectations.

Johansen's multivariate approach of cointegration analysis has been chosen as it allows testing of the cointegration rank. Further, it allows to test overidentifying restrictions on the cointegration vectors and also facilitates testing for weak exogeneity of the regressors. The sample of the present study covers the EMS period. Because weak exogeneity of the variables of the money demand equation is rejected for the EMS period, modelling German money demand using dynamic single equation estimation by OLS would result in inefficient estimators. Therefore, the long-run relationships are analysed within a multivariate framework. A further argument for employing a multivariate approach is that it allows for more than one long-run relationship between the variables and thereby permits other long-run relationships in addition to the money demand relation to influence the transmission process of monetary policy. ${ }^{2}$ The only study on German monetary policy (to the knowledge of the author) which is extensively testing within the Johansen procedure is Juselius (1996). In contrast to her work, this paper considers the EMS period and includes the weighted own rate of M3 rather than a deposit rate. A linear time trend is not included here. These differences have important implications for the long-run relationships found in the analysis.

The methodological approach of the present study differs from comparable analyses in the application of univariate as well as multivariate tests of the order of integration of the variables. The univariate procedures test the null hypothesis of nonstationarity, whereas stationarity is tested under the null within the multivariate approach. As the structural break of German reunification has to be taken into account, the Perron test (Perron, 1989) is applied in addition to the ADF test. In the multivariate model a step dummy re-

\footnotetext{
1 See e.g. Issing (1995) and König (1996) for a more detailed discussion of the monetary policy of the Bundesbank.

${ }^{2}$ This is the main reason why a multivariate approach is employed, as the asymptotically efficient multivariate maximum likelihood estimator is not to be preferred over single equation estimation in general. Other single equation estimation methods do not imply inefficiency, e.g. the fully modified estimator, which has been shown to be asymptotically equivalent to systems procedures such as Johansen's maximum likelihood estimation (Phillips and Hansen, 1990).
} 
stricted to the long-run as well as two unrestricted impulse dummies are included. As the inclusion of the step dummy changes the asymptotic distribution of the test statistic, new critical values have been simulated. Additionally, empirical critical values have been generated using a bootstrap procedure to account for the small sample analysis. The stable cointegration vectors that are found in the analysis are consistent with economic theory.

The paper is organised as follows: Section two presents a short overview of recent empirical studies on money demand, the term structure of interest rates and the Fisher equation. In the third section, the variables employed in this analysis are described and a preliminary data analysis is carried out. A vector autoregressive model is estimated and the Johansen test for the cointegration rank is applied in section four. Section five presents a short exposition of the economic theories relevant in the present context. Restrictions are tested on the cointegration space according to the suggestions of economic theory. In section six, the resulting cointegration vectors are interpreted and the stability of these long-run relationships is analysed, while section seven contains concluding remarks.

\section{Recent empirical literature}

The present analysis, set in a multivariate framework, is based on a system including the variables money, income, inflation rate and a long- as well as a short-term interest rate. Economic theory suggests three long-run relationships between these variables: a money demand relation, an interest rate spread and a Fisher relation. Long-run stationarity of these relationships relevant for monetary policy is tested and found for a period including German reunification. Most of the literature on German monetary policy concentrates on one of the long-run relationships considered in this study. A number of recent empirical studies will be discussed in the following.

The focus of many empirical studies on German monetary policy has been on the money demand function, since a stable money demand is a precondition for a policy of monetary targeting as pursued by the Bundesbank. In other countries, such as the US and the UK, targeting monetary aggregates has been abandoned because financial innovations led to instabilities in the money demand. Financial innovations have not played a very important role in Germany so far, but the question has been raised whether money demand is still stable after German reunification. One aim of this study is to find an answer to this question. There have been a large number of money demand studies for Germany. During the last years, cointegration methodology has become a standard tool for the analysis of the demand for money. Several authors analyse German money demand for M3 before German reunification using a cointegration approach, for example von Hagen and Neumann (1988), Gaab and Liedtke (1992), Beyer (1994) and Biefang-Frisancho Mariscal and Trautwein (1994). A number of studies have been presented analysing German money demand for M3 for a sample period including German reunification. Most of these studies place their emphasis on single equation modelling, as the Monthly Report of the Bundesbank (Bundesbank, 1995b), Issing and Tödter (1995), Kole and Meade (1995), Tullio, de Souze and Giucca (1996), Gaab (1996), Gaab and Mullineux (1996), Scharnagl (1996), König (1996), Wolters, Teräsvirta and Lütkepohl (1996) and Wolters and 
Lütkepohl (1997). ${ }^{3}$ The main focus of the studies cited varies, but all find that German money demand is stable if they model German reunification by including dummy variables.

To test for the cointegration rank, Johansen's maximum likelihood rank test is applied in some of these studies. In contrast to the present study, the authors usually derive a cointegration rank of one and proceed to carry out their analysis within a single equation error correction framework. Very few studies present a test for weak exogeneity of the variables of the money demand function to justify their single equation approach, e.g. Hansen and Kim (1995). ${ }^{4}$

An extensive literature on the US term structure of interest rates provides empirical evidence for the expectation hypothesis of the term structure (see e.g. Fama (1984, 1990), Campbell and Shiller (1987, 1991), Mishkin (1992), among others). A survey on the term structure literature can be found in Shiller (1990). Cointegration methodology has been used in recent studies in a univariate as well as multivariate context. Wallace and Warner (1993), for example, employ the Johansen procedure to test for the term structure of interest rates and the long-run Fisher effect using US data. The focus of the term structure literature varies. Some studies rather concentrate on the longrun relationship between short-term and long-term interest rates. Some other papers analyse the predictive performance of the spread for the development of the short-term and/or the long-term rate. Alternatively, the predictive performance of the term structure for the development of the inflation rate (e.g. Tzavalis and Wickens (1996)) or the market expectations with respect to future inflation (e.g. Schich (1996)) is analysed. This is relevant for the policy of the Bundesbank as the conduct of monetary policy relies on the development of indicators of current and expected future macroeconomic conditions. The Bundesbank monitors the development of the term structure as an indicator for inflationary expectations (see e.g. Schich (1996)). ${ }^{5}$

There is mixed evidence with respect to German term structure data. Mankiw (1986) finds puzzling results for a number of countries including Germany. Hardouvelis (1994) analyses the term structure of the Group of Seven $(\mathrm{G} 7)$ countries. He concludes that the empirical findings, except for the US, do not contradict the expectations hypothesis. Hassler and Nautz (1997) and Wolters (1995) have analysed monthly data and do not find empirical evidence for the expectation theory of the term structure with respect to shortterm and long-term rates. In contrast, a cointegration relationship between the bond rate and the three months money market rate has been found by Hansen (1997) and Juselius (1996) using quarterly data. Wolters (1997) finds cointegration between interest rates of different maturities analysing monthly data, but not a $(1,-1)$-relationship as predicted by the expectation theory. The interest rate data being used in the mentioned studies vary, but only

\footnotetext{
${ }^{3}$ For a more detailed overview of the literature on German money demand, see for example Scharnagl (1996).

${ }^{4}$ Multivariate analyses of money demand have been carried out for other countries than Germany. Hendry and Doornik (1994) have presented an analysis for the UK, whereas Hoffman and Rasche (1996) analyse US data.

${ }^{5}$ For a discussion of the information content of the term structure for inflation expectations, see also Gerlach (1995). An analysis of the relationship between the term structure of interest rates and monetary policy can be found in Kugler (1996).
} 
Wolters et al. (1996) test the same data as in the present study and find a stationary spread between the bond rate and the weighted own interest rate of M3 using the ADF test. The different results of the above cited studies indicate sensitivity of the analysis to the periodicity of the data.

The Fisher effect has been analysed and tested by MacDonald and Murphy (1989) for several countries, by Mishkin (1992) using US data and by Yuhn (1996) for a number of countries including Germany. Mishkin (1992) finds mixed results for the US employing the Engle-Granger procedure, as the existence of the Fisher effect depends on the sample period considered. In contrast, the above mentioned study by Wallace and Warner (1993) applies the Johansen procedure and finds strong evidence of a long-run Fisher effect within a two-dimensional system for the US and Japan, and also for Germany. Hoffman and Rasche (1996) find a money demand relation, an interest rate spread and a Fisher relation within a system of five variables, applying the Johansen procedure to US data. An extensive empirical analysis of the US Fisher relation can also be found in Crowder and Hoffman (1996), who illustrate the advantage of using Johansen's maximum likelihood approach in this context by a series of Monte Carlo experiments. For Germany, Kirchgässner and Wolters $(1990,1993)$ do find rather weak empirical evidence for the Fisher effect in an analysis based on monthly data and set into a singleequation context. In contrast, Yuhn (1996) has tested for the Fisher relation in a multivariate framework using the Johansen procedure and found evidence for the stationarity of the real interest rate. Overall, it seems that empirical evidence for the Fisher relation is more likely to be found in a systems approach than in a single-equation framework.

\section{Data}

This study is based on quarterly data covering the sample period from 1979(1), the year of the foundation of the European Monetary System, to 1994(2), thereby including German reunification. As the study aims to draw conclusions with respect to monetary policy in Germany, a special focus of the study is on the question whether a stable money demand relationship still exists in Germany. A stable money demand is a precondition for the policy of monetary targeting. Consequently, the variables of the model are mainly chosen to model German money demand.

Since targets for M3 are announced by the Bundesbank, the monetary aggregate M3 has been taken as a proxi for money demand. ${ }^{6}$ Nominal and real money in logarithms are denoted as $m 3^{n}$ and $m 3^{r}$, respectively. Further variables are included to capture the notion of money demand for transaction purposes as well as the demand for money as a part of portfolio choice decisions. The real GNP (in prices of 1985) is taken as a transaction or income

\footnotetext{
${ }^{6}$ A number of papers on German money demand have concentrated on a comparison of the stability of money demand functions for simple-sum M3 and Divisia monetary aggregates (e.g. Gaab and Mullineux (1996), Gaab (1996) and Tödter (1994)) with a special emphasis on the influence of financial innovations. As these studies conclude that Divisia can cope better with financial innovations, but that in Germany the difference in comparison with simple-sum aggregates is not sufficiently distinct to justify a change in the intermediate target for monetary policy, this study concentrates on the simple-sum aggregate M3.
} 
variable ${ }^{7}$ and its logarithm is denoted as $y^{r}$; the logarithm of the deflator of GNP (nominal GNP divided by real GNP), denoted $p$, represents the development of the prices. Both a long-term and a short-term interest rate are employed in the analysis. The long-term interest rate is the average interest rate for bonds in circulation (Umlaufsrendite inländischer Inhaberschuldverschreibungen), representing opportunity costs for holding money. The short-term interest rate is a constructed interest rate representing the own rate of M3. The interest rates on the individual components of M3 are weighted according to their respective contribution to M3. For the period 1979(1)-1990(2) the yield on time deposits is weighted by 0.25 while the yield on saving deposits is weighted by 0.41 . For the period $1990(3)-1994(2)$ the weights are 0.30 and 0.33 , respectively. The interest rates of currency and sight deposits are zero and, therefore, are not included in the own rate of M3. The weighted interest rate is employed rather than the three-months FIBOR which has often been used in ealier studies on German money demand, but does not really represent the own rate of M3 and can lead to an implausible sign of the coefficient. The interest rates, denoted $r^{l}$ and $r^{w}$, are the same as employed by Tödter (1995) and Wolters et al. (1996), but enter the model separately to be able to test the cointegration relationship between the interest rates in the multivariate framework. The inflation rate $(\Delta p)$ is incorporated in the model. This variable may represent opportunity costs of holding money with respect to investments in real capital. ${ }^{8}$ No currency substitution term is introduced into the model, as Tullio et al. (1996) and Bundesbank (1995a) find very little evidence for currency substitution for a sample period including German reunification. Our own analyses with different terms to represent the substitution between domestic and foreign currency confirm this result.

The data are taken from the data bases of the Bundesbank and the DIW. ${ }^{9}$ Quarterly seasonally unadjusted data are employed in the analysis. Fig. 1 displays the time series graphically.

To test for the null hypothesis of non-stationarity of the real monetary aggregate and the GNP, an extension of the Augmented-Dickey-Fuller methodology is applied as suggested by Perron (1989) because these variables exhibit a structural break. An auxiliary regression is carried out where $m 3^{r}$ is regressed on a constant $(\mathrm{C})$, a linear deterministic trend $(\mathrm{T})$, a step dummy (Dstep is 1 after 1990(2) and 0 otherwise) and seasonal dummies (SD). This approach corresponds to model (A) in Perron (1989) which allows for an exogenous change in the level of the series under the null hypothesis. With respect to $y^{r}$ model (C) in Perron (1989) is considered, which allows for a change in the level of the series as well as in the rate of growth. Consequently, a similar auxiliary regression as for $m 3^{r}$ is carried out, but with an additional term incorporated, i.e. the stepdummy multiplied by the trend (Dstep x T), to allow for a break in the trend. The critical values for these tests are taken from Perron (1989) for $\lambda=0.8$ where $\lambda$ is the time of the break in the series relative to the total sample size. The original Augmented Dickey Fuller Test (ADF) is

\footnotetext{
${ }^{7}$ In Germany, only data on financial wealth are available. Therefore, wealth was not included in the model.

${ }^{8}$ Wolters and Lütkepohl (1997, Appendix A) show that the inflation rate could possibly influence the long-run demand for real money even if it is not assumed to influence desired nominal money demand.

${ }^{9}$ For further details on the data, see Appendix.
} 

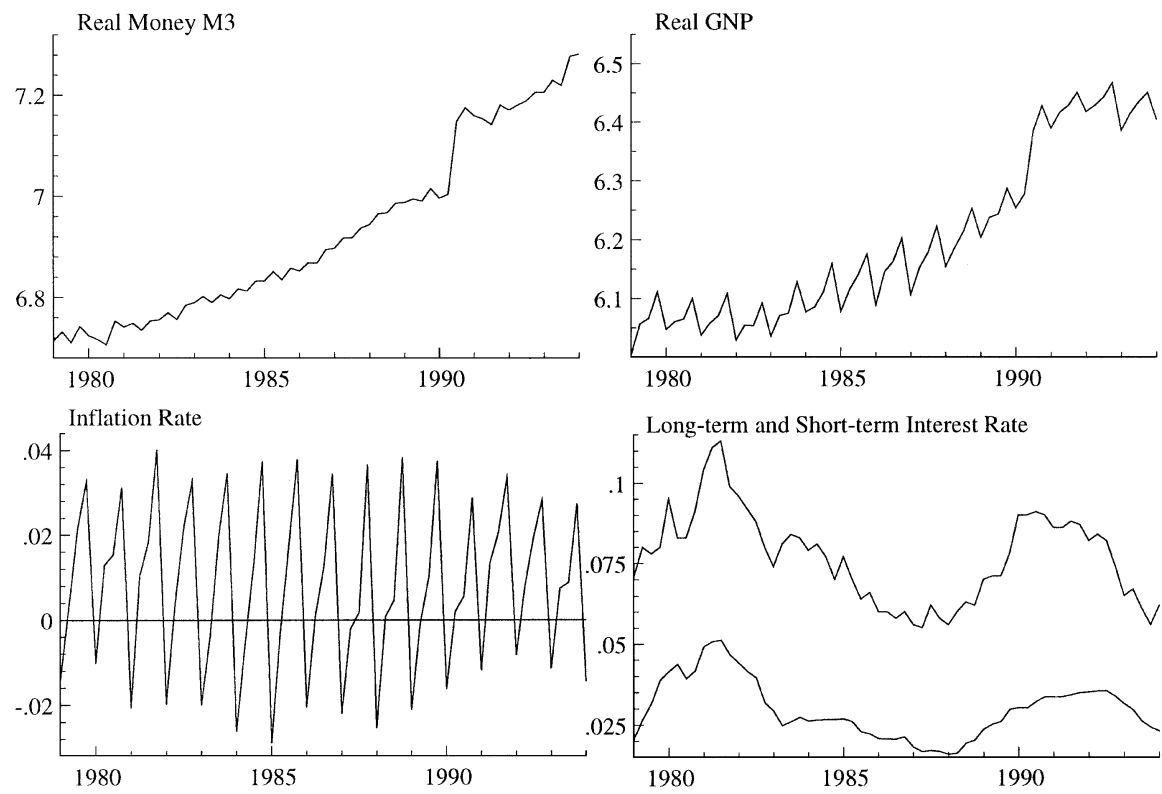

Fig. 1. Data

applied to test for a unit root in $\Delta m 3^{r}$ and $\Delta y^{r}$ as well as in the inflation rate, the interest rates and the respective first differences. $\Delta m 3^{r}$ and $\Delta y^{r}$ are only tested for the period 1979(1) until 1989(4) and are assumed to be stationary after German reunification because critical values to test stationarity of the respective model for differenced time series with structural break are not available yet. ${ }^{10}$ Testing long-run price homogeneity of the demand for money appears to be problematic. The application of the same procedure as applied to test for the degree of integration of $m 3^{r}$ derives that nominal money $m 3^{n}$ is $\mathrm{I}(1)$ whereas $p$ appears to be $\mathrm{I}(2)$. Therefore, long-run price homogeneity of the money demand has been assumed in this study. One argument for this strategy is that the demand for money is a demand for real balances (see e.g. Laidler (1993, pp 160-163)). Other studies, e.g. Gaab (1996), have found a price elasticity close to one using Johansen's maximum likelihood procedure. Wolters et al. (1996) also assume price homogeneity of the demand for money. Therefore, the following analysis has been carried out under the working assumption of long-run price homogeneity of money demand.

Table 1 presents the results of the unit root tests. ${ }^{11} \mathrm{~A}$ maximum of five lags has been chosen. $k$ denotes the longest significant lag according to the $t$ statistic. A constant and seasonal dummies have been included in the ADF test for $\Delta m 3^{r}, \Delta y^{r}$, the inflation rate and the change in the inflation rate, whereas for the interest rates only a constant has been incorporated. The unit root tests suggest that all variables are $\mathrm{I}(1)$.

\footnotetext{
10 The multivariate tests presented later clearly reject stationarity of the level variables, and therefore $m 3^{r}$ and $y^{r}$ can be considered to be at least $\mathbf{I}(1)$.

${ }^{11}$ PcGive 8.0 and PcFiml 8.0 by Doornik and Hendry (1994a, 1994b) have been used for the computations presented in this paper.
} 
Table 1. Augmented Dickey Fuller test/Perron test

\begin{tabular}{|l|l|l|l|l|}
\hline variable & auxiliary regression & $k$ & $t$-statistic & $\begin{array}{c}\text { critical value } \\
(5 \%)\end{array}$ \\
\hline$m 3^{r}$ & $C, T$, Dstep,$S D$ & 0 & -2.13 & $-3.75^{(1)}$ \\
$y^{r}$ & $C, T$, Dstep $\times T$, Dstep, $S D$ & 4 & -1.67 & $-4.04^{(2)}$ \\
$\Delta p$ & & 5 & -2.41 & -2.91 \\
$r^{l}$ & & 3 & -2.38 & -2.91 \\
$r^{w}$ & 4 & -2.68 & -2.91 \\
$\Delta m 3^{r}$ & & 0 & $-7.82^{* *}$ & $-2.93^{(3)}$ \\
$\Delta y^{r}$ & & 0 & $-7.31^{* *}$ & $-2.93^{(3)}$ \\
$\Delta \Delta p$ & & 5 & $-4.30^{* *}$ & -2.91 \\
$\Delta r^{l}$ & & 2 & $-3.53^{*}$ & -2.91 \\
$\Delta r^{w}$ & & 0 & $-4.44^{* *}$ & -2.91 \\
\hline
\end{tabular}

Note: $k$ is the number of lagged differences included in the ADF test (according to the highest significant number of lags of a maximum of 5 lags); ** and $*$ denote significance at a $1 \%$ and a $5 \%$ level respectively; critical values are from MacKinnon (1991), except for the values marked by (1) and (2); (1): critical value of $\operatorname{Model}(\mathrm{A})$ in Perron (1989), $\lambda=0.8 ;(2)$ : critical value of Model(C) in Perron (1989), $\lambda=0.8$; (3): ADF test for the period 1979(1) to $1989(4)$

\section{The Johansen procedure}

The Johansen procedure (Johansen, 1988, 1991 and 1995) is applied to the data, as it allows the estimation of multiple cointegrating vectors. ${ }^{12}$ Johansen's maximum likelihood procedure is based on a linear system:

$$
X_{t}=v+\sum_{i=1}^{k} A_{i} X_{t-i}+\Phi D_{t}+u_{t}, \quad t=1, \ldots, T,
$$

where $X_{t}$ is the vector with the $n$ variables of the system, assuming $X_{t} \sim \mathrm{I}(d)$ with $d \leq 1$ and $u_{t} \sim N(0, \Sigma) .{ }^{13}$ The $A_{i}$ are coefficient matrices and $D_{t}$ is the vector of deterministic terms which in this analysis includes step and impulse dummies as well as seasonal dummies. A reparameterization of this $\operatorname{VAR}(k)$ results in an error correction form:

$$
\Delta X_{t}=v+\Pi X_{t-1}+\sum_{i=1}^{k-1} \Gamma_{i} \Delta X_{t-i}+\Phi D_{t}+u_{t}, \quad t=1, \ldots, T
$$

Here, $\Pi$ is an $n \times n$ coefficient matrix which can be factorized according to the

\footnotetext{
${ }^{12}$ Although the Johansen procedure has been found to be sensitive towards misspecification (e.g. Reimers (1992)), it shows a better performance in many respects than alternative tests (see e.g. Haug (1996)). For a comparison of the performance of different cointegration tests, see e.g. Reimers $(1992)$, Toda $(1994,1995)$ and Haug (1996) with respect to the test of the cointegration rank and e.g. Hargreaves (1994) concentrating on the comparison of the estimators of the cointegration relationships.

${ }^{13}$ The case of $\mathrm{I}(2)$ variables is not considered as the variables involved in this study are $\mathrm{I}(0)$ or $\mathrm{I}(1)$.
} 
number $r(0 \leq r \leq n)$ of linearly independent cointegration vectors:

$$
\Pi=\alpha \beta^{\prime} .
$$

where $\alpha(n \times r)$ is the matrix of the adjustment coefficients and $\beta^{\prime}(r \times n)$ is the matrix of cointegrating vectors. The matrix $\Pi$ has rank $r, r k(\Pi)=r$.

The application of the Johansen procedure results in a maximum likelihood estimation of the parameters of the above system. The Johansen procedure is based on the solution of a generalized eigenvalue problem. ${ }^{14}$ The eigenvalues are ordered, starting with the largest eigenvalue. The number of eigenvalues significantly different from zero indicates the number of cointegration relationships $r$. A likelihood ratio test is carried out by testing the hypothesis $H_{0}: r k(\Pi)=r$ against $H_{1}: r k(\Pi)=r+1$ for the maximum eigenvalue test or $H_{0}: r k(\Pi)=r$ against $H_{1}: r k(\Pi) \geq r+1$ for the trace test. The test statistics are $\left.-T \ln \left(1-\hat{\lambda}_{r+1}\right)\right)$ and $\left.-T \sum_{i=r+1}^{n} \ln \left(1-\hat{\lambda}_{i}\right)\right)$, respectively. The $\lambda_{i}$ represent the ordered eigenvalues of the system. A testing sequence is carried out for $r=1,2, \ldots$ and continues until the null hypothesis is not rejected any more.

\subsection{The initial VAR}

An unrestricted vector autoregressive model (VAR), including the variables $m 3^{r}, y^{r}, r^{l}, r^{w}$ and $\Delta p$, a constant and seasonal dummies, has been estimated, first. An impulse dummy (D903i), which is one in 1990(3) and null otherwise, has been introduced into the model unrestrictedly. Further, a step dummy (Dstep), which is null until 1990(2) and one thereafter, has been restricted to enter the long-run relationship. An additional impulse dummy, D933i, has been included for 1993(3) to account for the effects of the turbulences within the European Monetary System in the summer of 1993 which led to the widening of the currency bands from $\pm 2.25 \%$ to $\pm 15.0 \%$ on August 2nd. A VAR order has been chosen on the basis of the Schwarz and the HannanQuinn criterion. These order selection criteria are consistent even for a nonstationary system. ${ }^{15}$ The Schwarz criterion indicates a VAR order of $k=1$, whereas the Hannan-Quinn criterion selects a VAR order of $k=2$. As an Ftest of model reduction rejects the reduction to a $\operatorname{VAR}(1)$ at a $1 \%$ significance level and misspecification tests show high autocorrelation for the $\operatorname{VAR}(1)$, a VAR order of $k=2$ is chosen.

Single equation misspecification tests for the $\operatorname{VAR}(2)$ reveal no misspecification except some autocorrelation in the income equation and rejection of normality with respect to the short-term interest rate equation at a $5 \%$ significance level (see Table 2). The vector tests for misspecification do not exhibit any autocorrelation, but normality is rejected at a $5 \%$ significance level. Since the Johansen procedure does not strictly depend on the normality assumption (Lütkepohl, 1991), the $\operatorname{VAR}(2)$ is taken as the basis for further

\footnotetext{
14 More technical details of this approach, originally presented by Johansen (1988), can be found in Lütkepohl (1991), Banerjee, Dolado, Galbraith and Hendry (1993) and Hamilton (1994), among others. Johansen (1995) presents the generalized version allowing for dummy variables considered here.

${ }^{15}$ For details about the properties of these order selection criteria, see e.g. Lütkepohl (1991).
} 
Table 2. Single equation misspecification tests $(\operatorname{VAR}(2))$

\begin{tabular}{|c|c|c|c|}
\hline Test & AR 1-4 & Normality & ARCH 4 \\
\hline \multirow{2}{*}{$m 3^{r}$} & 0.941 & 1.900 & 2.037 \\
& {$[0.450]$} & {$[0.387]$} & {$[0.109]$} \\
$y^{r}$ & $3.698^{*}$ & 1.907 & 0.883 \\
& {$[0.012]$} & {$[0.386]$} & {$[0.483]$} \\
$r^{l}$ & 0.980 & 2.932 & 0.416 \\
& {$[0.429]$} & {$[0.231]$} & {$[0.796]$} \\
$r^{w}$ & 0.903 & $6.318^{*}$ & 0.205 \\
& {$[0.471]$} & {$[0.043]$} & {$[0.934]$} \\
$\Delta p$ & 2.377 & 5.381 & 0.733 \\
& {$[0.068]$} & {$[0.068]$} & {$[0.576]$} \\
\hline
\end{tabular}

Note: $p$-values in parentheses; * denotes significance at a $5 \%$ level

Table 3. Vector tests $(\operatorname{VAR}(2))$

\begin{tabular}{|l|c|c|}
\hline Test & test statistic & $p$-value \\
\hline AR $1-4$ & 1.091 & {$[0.329]$} \\
Normality & $20.574^{*}$ & {$[0.024]$} \\
\hline
\end{tabular}

Note: $p$-values in parentheses; ${ }^{*}$ denotes significance at a $5 \%$ level

analysis. The misspecification tests presented include single equation misspecification tests (LM test for autocorrelated residuals (Harvey, 1990), test for normality (Doornik and Hendry, 1994a), LM test for autocorrelated squared residuals (Engle, 1982) and vector tests as described in Doornik and Hendry (1994a) (vector error autocorrelation test, vector normality test). ${ }^{16}$ For the investigation of the parameter constancy, the 1-step residuals and the break-point Chow test (Chow, 1960) based on recursive estimation have been computed. The 1-step residuals (Fig. 2) only indicate a slight problem in the end of 1993. This is probably due to the special factors, e.g. changes in tax regulations, that have led to an increase of money demand in winter 1993 (see Deutsche Bundesbank (1994)). Introducing an additional impulse dummy for 1993(4) improves the 1-step residuals. However, as it does not improve the fit of the VAR substantially, it has not been included in the model presented. The Chow F-tests are scaled by their 5\% significance levels and none of their values exceed unity (Fig. 3). Thus, the VAR is considered to be stable.

\subsection{The Johansen Test for the Cointegration Rank}

The results of the Johansen test based on the VAR(2) are given in Table 4. As available asymptotic critical values are not appropriate because a step dummy

16 Tests for normality are chi-square tests, the other tests are in $\mathrm{F}$ form. 


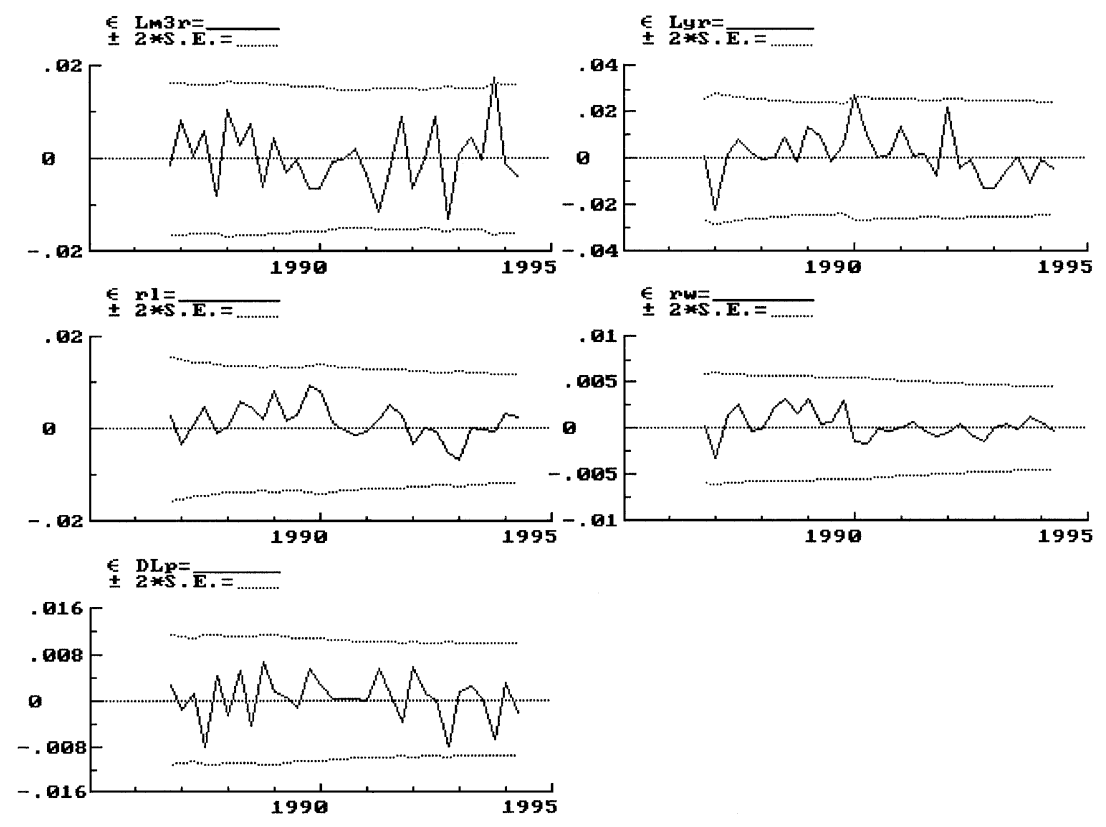

Fig. 2. 1-step residuals (recursive estimation statistics)

N+ $\operatorname{Lm} 3 r=$

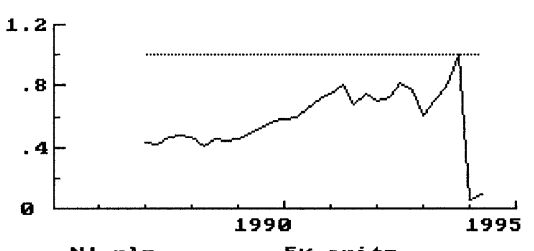

$N+\mathbf{r l}=$

1.2
.8
.4
0

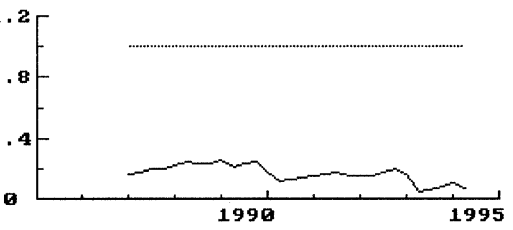

N† DLp $=$

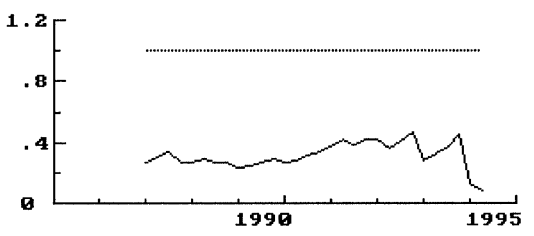

$N+\operatorname{Lg} \mathbf{r}=$ $5 \% \operatorname{crit}=$
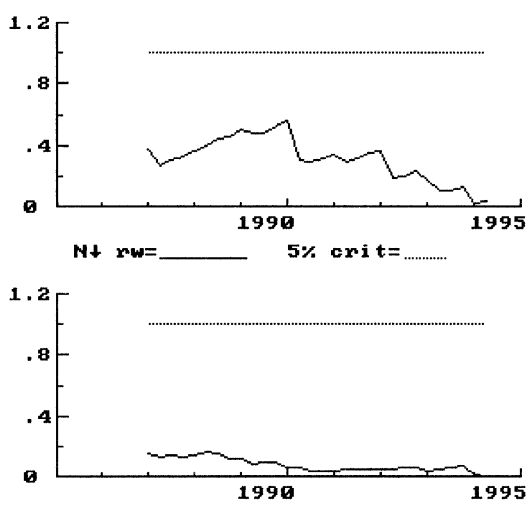

N+ CHOWs $=$

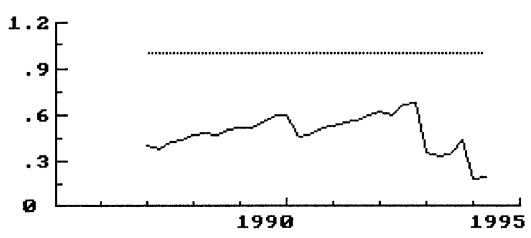

Fig. 3. Break-point Chow test 
Table 4. Johansen test for the cointegration rank

\begin{tabular}{|l|l|l|l|}
\hline$H_{0}:$ rank $=r$ & $\begin{array}{l}\text { trace } \\
\text { statistic }\end{array}$ & $\begin{array}{l}95 \% \\
\text { (asymptotic) }\end{array}$ & $\begin{array}{l}95 \% \\
\text { (bootstrap) }\end{array}$ \\
\hline$r=0$ & $126.5^{*}$ & 79.7 & 94.5 \\
$r=1$ & $67.99^{*}$ & 56.1 & 65.1 \\
$r=2$ & $41.34^{*}$ & 36.2 & 38.4 \\
$r=3$ & 16.24 & 19.8 & 23.4 \\
$r=4$ & 3.186 & 5.9 & 3.2 \\
\hline
\end{tabular}

Note: * denotes significance at a $5 \%$ level; critical values are the $95 \%$ quantiles of the asymptotic distribution, simulated with the program DisCo (Nielsen, 1994), and the $95 \%$ quantiles derived within a bootstrap procedure

is included in the model, the program DisCo by Nielsen (1994) has been used to simulate the $95 \%$ quantiles of the asymptotic distribution of the test statistic where a constant enters the model unrestrictedly and the step dummy for reunification is restricted to the long-run. ${ }^{17}$

The trace test supports a cointegration rank of three. To account for the fact that the sample underlying this analysis is quite small, the empirical critical values have been derived from a bootstrap procedure allowing for a restricted step dummy, unrestricted impulse dummies and a constant. ${ }^{18}$ Based on these critical values, the trace test still indicates a cointegration rank of three. Therefore, a cointegration rank of $r=3$ is assumed in the following.

\section{Testing restrictions on the cointegration space}

The Johansen procedure facilitates tests of restrictions on the adjustment coefficients $\alpha$ and the cointegration vectors $\beta$. In these tests the likelihood function is maximized allowing for restrictions on $\alpha$ and/or $\beta .{ }^{19}$ Consistent with the result of the test for the cointegration rank, the likelihood ratio tests for testing restrictions are carried out under the assumption of three cointegration vectors.

\subsection{Weak exogeneity and stationarity of the variables}

In a first step, weak exogeneity of the variables in the money equation is tested. Weak exogeneity of these variables would be a precondition to get efficient estimators from single equation estimation of the German money demand by OLS. Testing restrictions on the $\alpha$-coefficients results in the rejection of weak exogeneity for real GNP at a 5\% significance level and for the inflation rate at a $1 \%$ significance level. As weak exogeneity is rejected, the cointegration parameters are inherently cross-linked between the equations,

\footnotetext{
17 Simulations have been based on 10000 replications and 400 observations.

18 The bootstrap procedure has been based on 10000 replications.

19 For an exposition of this procedure and applications to monetary data, see Johansen and Juselius (1990, 1994) and Johansen (1995).
} 
Table 5. LR Tests for cointegration relationships $(r=3)$

\begin{tabular}{|c|c|c|c|c|c|c|c|c|}
\hline & $m 3^{r}$ & $y^{r}$ & $r^{l}$ & $r^{w}$ & $\Delta p$ & Dstep & & $p$-value \\
\hline \multicolumn{9}{|l|}{ money } \\
\hline$H_{1}: \beta^{\prime}=$ & 1 & 0 & 0 & 0 & 0 & -0.359 & ) & $0.0009 * *$ \\
\hline$H_{2}: \beta^{\prime}=$ & 1 & -1 & 0 & 0 & 0 & -0.052 & ) & 0.064 \\
\hline \multicolumn{9}{|l|}{ income } \\
\hline$H_{1}: \beta^{\prime}=$ & 0 & 1 & 0 & 0 & 0 & -0.299 & ) & $0.0001 * *$ \\
\hline \multicolumn{9}{|c|}{ interest rates } \\
\hline$H_{1}: \beta^{\prime}=$ & 0 & 0 & 1 & 0 & 0 & 0 & ) & $0.010 * *$ \\
\hline$H_{2}: \beta^{\prime}=$ & 0 & 0 & 0 & 1 & 0 & 0 & ) & $0.006 * *$ \\
\hline$H_{3}: \beta^{\prime}=$ & 0 & 0 & 1 & -1 & 0 & 0 & ) & 0.090 \\
\hline$H_{4}: \beta^{\prime}=$ & 0 & 0 & 1 & -1.502 & 0 & 0 & ) & 0.818 \\
\hline \multicolumn{9}{|l|}{ inflation } \\
\hline$H_{1}: \beta^{\prime}=$ & 0 & 0 & 0 & 0 & 1 & 0 & ) & $0.016^{*}$ \\
\hline$H_{2}: \beta^{\prime}=$ & 0 & 0 & 1 & 0 & -13.30 & 0.052 & ) & 0.741 \\
\hline$H_{3}: \beta^{\prime}=$ & 0 & 0 & 0 & 1 & -8.665 & 0.003 & ) & 0.767 \\
\hline$H_{4}: \beta^{\prime}=$ & 0 & 0 & 1 & 0 & -4 & 0.013 & ) & $0.017^{*}$ \\
\hline$H_{5}: \beta^{\prime}=$ & 0 & 0 & 0 & 1 & -4 & 0.013 & ) & 0.096 \\
\hline$H_{6}: \beta^{\prime}=$ & 0 & 0 & 0 & 1 & -4 & 0 & ) & $0.009 * *$ \\
\hline
\end{tabular}

Note: $* *$ and $*$ denote significance at a $1 \%$ and $5 \%$ level respectively; the $p$-values correspond to the LR test of the respective restriction; the values not equal to 1,0 or -4 are freely estimated

i.e. a single equation estimation will lead to a loss of information (Banerjee et al., 1993). To get a fully efficient estimator, a multivariate approach to estimation is employed in the following. A multivariate procedure is preferred over a single-equation approach to account for all three cointegrating relationships because the aim of the study is not only the analysis of the German money demand, but of the conditions for German monetary policy in general characterized by the long-run relationships between important macroeconomic variables.

A number of restrictions have been tested on single cointegrating vectors in a multivariate framework. The results are presented in Table 5. First, stationarity of each variable in the system has been tested. Stationarity of money, income and inflation is postulated in the respective hypotheses $H_{1}$. Stationarity of each interest rate is tested in the hypotheses $H_{1}$ and $H_{2}$ for the interest rates. Stationarity is rejected for all variables in the system. These results are consistent with the results of the univariate tests of the order of integration. Note, that, in contrast to the Augmented Dickey Fuller test, the null hypothesis is stationarity here. As stationarity is rejected, this is an even stronger indication that the variables are actually non-stationary. To test stationarity of $y^{r}$ and $m 3^{r}$ the step dummy for reunification has been included.

\subsection{Tests of long-run relationships suggested by economic theory}

In the following, restrictions on the cointegration vectors are tested, as $\beta$ is not identified within the Johansen procedure. The restrictions tested on single co- 
integrating vectors are motivated by economic theory of the long-run relationships between the variables considered in this analysis. Therefore, a short exposition is given for each of the relevant theories.

Economic theory of money demand suggests two main motives for holding money: Money is held for transaction purposes and as part of a portfolio. ${ }^{20}$ According to the transaction motive, money is held as a medium of exchange and as an inventory to balance the time gap between income and expenditures (Baumol (1952), Tobin (1956)). In a broader sense, the demand for money can be considered as a part of a portfolio decision (Tobin (1958), Friedman (1956)), where assets are allocated within a portfolio with the aim of profit maximization. In this case, holding money is considered as one alternative to allocate assets. On the basis of the theories mentioned, money demand can be considered to be mainly a function of income and of opportunity costs of holding money as well as an own interest rate of money:

$$
M^{r}=f\left(y^{r}, r^{l}, r^{w}, \Delta p\right) .
$$

These variables enter the system considered in this study. The income variable can be taken as a proxi for the influence of the volume of transactions on the demand for money. The spread between the long-term and the short-term interest rate represents the opportunity costs of holding money in comparison to holding other financial assets, and the inflation rate can be interpreted as opportunity costs of holding money compared to investments into real capital. Since testing restrictions on a single cointegration vector requires more than $r-1$ restrictions for the vector to be overidentified, the money demand relation will be tested simultaneously with the other relationships, later.

In the context of testing single cointegration vectors, the velocity of money, which has a considerable impact on the transmission process of monetary policy, can be tested. Stationarity of the inverse velocity $\left(m 3^{r}-y^{r}\right)$ including the step dummy for reunification $\left(H_{2}\right)$ is tested and not rejected, but the $p$ value of the likelihood ratio (LR) statistic is quite close to the $5 \%$ significance level. Therefore, this result is considered with some doubt, especially as velocity in Germany is assumed to have a negative trend (see e.g. Issing and Tödter (1995)). The hypothesis of income homogeneity of money demand will be looked at again when simultaneous tests of three cointegration vectors are carried out.

The expectations theory of the term structure suggests a long-run one to one relationship between long-term and short-term interest rates. The expectations theory of the term structure can be formulated as

$$
R_{t}^{(k)}=\frac{1}{k} \sum_{i=0}^{k-1} E_{t} R_{t+i}^{(1)}+\phi_{k}
$$

Here, $R_{t}^{(k)}$ is the yield on a discount bond with $k$ periods to maturity. The model states that the yield on a $k$-period bond is given by the average of ex-

\footnotetext{
${ }^{20}$ The first indepth analysis of the motives that lead people to hold money can be found in the work of Keynes, especially in Keynes (1936). For an overview of the various lines of research in the theory of the demand for money, see e.g. Laidler (1993).
} 
pected future one-period short rates up to $k-1$ periods in the future. The symbol $\phi_{k}$ reflects a term premium, i.e. the predictable excess return on the $k$ period bond over the one-period bond which is assumed to be constant through time and depends on time to maturity $k$. The expectations theory of the term structure presented here is based on the hypothesis of rational expectations, as in Campbell and Shiller (1991). ${ }^{21}$ Wolters (1997) shows that according to the expectation hypothesis of the term structure every possible spread between two interest rates with different maturities is stationary. He also shows that the cointegration relation then must be $(1,-1)$. Table 5 shows, that a long-run $(1,-1)$ relationship between the two interest rates $\left(H_{3}\right)$ is not rejected by Johansen's likelihood ratio test. This result is consistent with the stationarity of the spread assumed by the expectations theory of the term structure. Therefore, the necessary condition for the expectation theory of the term structure to hold is fulfilled. As the $p$-value is slightly below the $10 \%$ significance level the LR test is repeated leaving the coefficient of the second interest rate unrestricted. The $p$-value turns out to be considerably higher than before.

The Fisher equation states that the nominal interest rate $r_{t}$ is given by

$$
r_{t}=r_{r, t}+\pi_{t}-\varepsilon_{t}
$$

where $r_{r, t}$ denotes the ex ante real interest rate, $\pi$ is the inflation rate and the forecast error $\varepsilon_{t}=\pi_{t}-E_{t-1} \pi_{t}$ (i.e. the current inflation rate minus the expectation of the current inflation rate) under rational expectations is white noise and therefore must be stationary. If $r_{t}-\pi_{t}$ is found to be stationary, that also means that the ex ante real interest rate $r_{r, t}$ is stationary, as the above equation can be reformulated to $r_{r, t}=r_{t}-\pi_{t}+\varepsilon_{t}$ (see e.g. Mishkin (1992)). Mishkin (1992) also pointed out that evidence supports the existence of a long-run rather than a short-run Fisher effect as has already been suggested by Fisher (1930). Further, arguments have been brought forward in the literature for a Fisher relation between the short-term yield and the inflation rate as well as the long-term interest rate and the inflation rate. ${ }^{22}$ In the LR tests presented in Table $5\left(\mathrm{H}_{2}\right.$ to $\left.\mathrm{H}_{6}\right)$ the Fisher equation has been tested for $r^{l}$ and $r^{w}$. Stationarity of a vector including the inflation rate and the long-term $\left(\mathrm{H}_{2}\right)$ or the short-term interest rate $\left(\mathrm{H}_{3}\right)$ is not rejected if the step dummy is included. For both interest rates, the full Fisher effect has been tested $\left(\mathrm{H}_{4}\right.$ and $\left.\mathrm{H}_{5}\right)$. The coefficient of the inflation rate has been transformed to account for using a quarterly inflation rate and interest rates measured in percent per year in the analysis. Therefore, the Fisher equation of the form

$$
r_{r, t}=r_{t}-\pi_{t}+\varepsilon_{t},
$$

where $\pi_{t}=4 \times \Delta p_{t}$ represents the full Fisher effect is tested. The coefficient of

\footnotetext{
21 The expectation hypothesis of the term structure has first been discussed in the work of Fisher, e.g. in Fisher (1930). For an exposition and applications of the model, see Shiller (1990), Campbell and Shiller (1991) and Pfann, Schotman and Tschernig (1995), among others.

${ }^{22}$ For theoretical arguments to consider long-term as well as short-term interest rates in the Fisher equation, see e.g. Wallace and Warner (1993). Yuhn (1996) also carries out tests using short- and long-term interest rates.
} 
Table 6. LR Tests of restrictions on $\beta^{\prime}(r=3)$

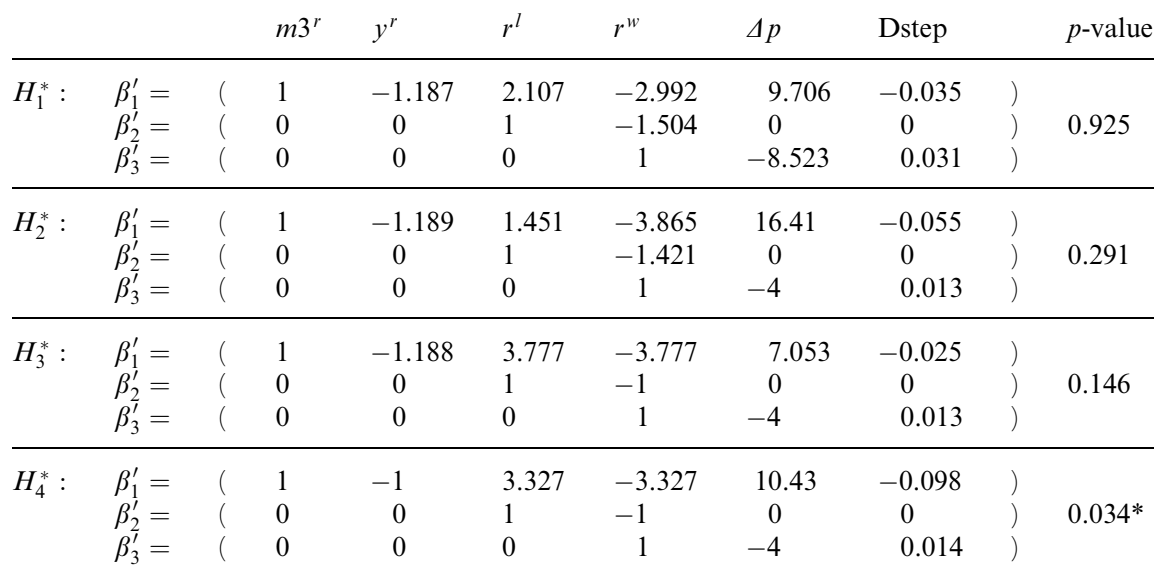

Note: * denotes significance at a 5\% level; the $p$-values correspond to the LR test of the respective restriction; the values not equal to 1,0 or -4 are freely estimated

-4 for the quarterly inflation rate implies a $(1,-1)$ cointegration vector between yearly nominal interest rates and the yearly inflation rate. The full Fisher effect is rejected if the long-term interest rate is included $\left(H_{4}\right) \cdot{ }^{23}$ For the short-term interest rate $\left(H_{5}\right)$ the full Fisher effect is not rejected at a 5\% significance level. If the step dummy is excluded $\left(H_{6}\right)$, the full Fisher effect is rejected which indicates that the structural break of reunification influences the Fisher relation. This, however, can be modelled by a dummy variable.

Based on the results of the LR tests of restrictions on single cointegrating vectors, simultaneous tests of economically reasonable long-run relationships have been carried out. The most interesting results are presented in Table 6 . The hypotheses tested all include a long-run relationship for money demand, a cointegration vector for the two interest rates and a third cointegrating vector including the inflation rate and the short-term interest rate.

In the first hypothesis the money demand vector is normalized on the monetary aggregate and is not restricted otherwise. The coefficient of the short-term interest rate in the second cointegrating vector is not restricted to -1 , as suggested by the expectations theory. The third vector of the first hypothesis representing the Fisher effect is normalized on the short-term interest rate, but the coefficient for the inflation rate is left unrestricted. These three vectors $\left(H_{1}^{*}\right)$ are simultaneously tested and are not rejected. In the next hypothesis $\left(\mathrm{H}_{2}^{*}\right)$ the full Fisher effect is imposed and is not rejected. If the cointegration vector between the interest rates is restricted to $(1,-1)$ and equality of the interest rate coefficients in the money demand relation is imposed in hypothesis $H_{3}^{*}$, the LR test does not reject these restrictions, even on a $10 \%$ significance level. If income homogeneity is additionally imposed, the LR test rejects $\left(\right.$ see $H_{4}^{*}$ ). This result is more plausible than the result for the

\footnotetext{
${ }^{23}$ For extended sample periods, the full Fisher effect is neither rejected for the long-term nor for
} the short-term interest rate. 
test of the single cointegration vector in $H_{2}$ (Table 5), which is in contrast to the assumption underlying the target formulation of the Bundesbank (allowing for a negative trend in velocity) and shows a $p$-value near the 5\% level. Therefore, the following analysis is based on the three cointegration relationships tested in hypothesis $H_{3}^{*} \cdot{ }^{24}$

As the results from the Johansen procedure have sometimes been found to depend on the sample and the lag order of the VAR underlying the analysis, the robustness of the result has been examined. Estimates and tests within Johansen's maximum likelihood procedure have been carried out for smaller samples. The results for the cointegration rank as well as the three specific cointegration vectors found for the sample period 1979(1) to 1994(2) appear to be considerably robust. Also, a similar result for the money demand equation has been found by Wolters et al. (1996) for a longer sample period starting in 1976(1) using a dynamic single equation procedure. Further, residualbased ADF tests have been carried out to check stationarity of the cointegration vectors. Nonstationarity is rejected for all three cointegration relationships and, therefore, the multivariate result is confirmed. The outcome of the Johansen procedure has not been compared with results based on other lag orders as the misspecified VAR(1) cannot be an appropriate basis for further tests. On the other hand, higher order VAR models include too many parameters relative to the number of observations.

\section{Cointegration vectors and their stability}

The first cointegrating vector can be interpreted as a long-run money demand relationship:

$$
m 3^{r}=1.188 y^{r}-3.777\left(r^{l}-r^{w}\right)-7.053 \Delta p+0.025 \text { Dstep. }
$$

All coefficients in this cointegration vector show the theoretically expected signs. The income elasticity is 1.188 and is therefore greater than unity. This result justifies the derivation of the yearly target for M3 announced by the Bundesbank which is based on the assumption that velocity is falling in Germany. An income elasticity greater than one can be due to wealth effects (monetary wealth does grow faster than the GNP) or can be caused by an increase of the unobservable transaction volume which is stronger than the increase in GNP (see e.g. Issing and Tödter (1995)). The elasticity for the inflation rate is found to be -0.071 , assuming a quarterly inflation rate of $1 \%$. This result is similar to the estimates that Wolters et al. (1996) obtained from a single equation approach. ${ }^{25}$

\footnotetext{
${ }^{24}$ It is not clear whether $H_{1}^{*}, H_{2}^{*}$ and $H_{3}^{*}$ are fully identified. However, if additional restrictions are imposed by excluding one of the interest rates and the inflation rate from the first cointegration vector to ensure identification (see Hoffman and Rasche (1996, p. 218)), tests resulted in the same value of the likelihood, as expected. Therefore, the vectors presented in $H_{1}^{*}$ to $H_{3}^{*}$ are compatible with an identified set of cointegration vectors. $H_{3}^{*}$ is taken as the basis of economic interpretation in section six since it allows a more plausible interpretation of the money demand equation.

25 The elasticity derived within the Johansen procedure is smaller than the elasticity of the inflation rate in the single equation estimate of Wolters et al. (1996), but the semielasticity of the interest rate spread representing opportunity costs of holding money is nearly the same as that obtained from the single equation approach by these authors, using the same variables.
} 
The second cointegrating vector is the spread between the long-term and the short-term interest rate:

$$
r^{l}-r^{w}
$$

This result implies that expectations of future short-term rates essentially determine the current long-term interest rates. This is in contrast to the findings of other authors (see section two) for data with different periodicity. The inclusion of a 3-months German money market rate as the short-term interest rate instead of the constructed own rate of M3 employed in the present study as well as the different sample periods and periodicity of the data might explain the differences in results. An ADF test based on the sample period considered in the present study also rejects non-stationarity of the spread.

The third cointegrating vector can be interpreted to represent the Fisher relation:

$$
r^{w}-\pi+0.013 \text { Dstep, }
$$

where $\pi$ is the yearly inflation rate. Therefore, $\pi=4 \times \Delta p$ with $\Delta p$ representing the quarterly inflation rate. $r^{w}$ represents the yearly weighted interest on assets included in M3. The full long-run Fisher effect, where the coefficient of the yearly inflation rate is unity, states that under rational expectations the inflation rate is the dominant force to determine the nominal interest rate. Notably, Yuhn (1996) found a long-run relationship between the inflation rate and a short-term as well as a long-term interest rate, analysing German data. However, in the present study stationarity of the real long-term rate is rejected. This might be due to a risk and liquidity premium for long-term assets. The coefficient estimated in $H_{3}$, Table 5 might indicate an overproportional reaction of the long-term interest rate to an increase in inflationary expectations. This is in line with the theory of liquidity preference according to Hicks (1939) which states that the risk premium increases the higher the maturity of a financial asset. Also, the long-run interest rate is largely determined by international capital markets (see e.g. Hansen (1997)).

The relationship between the inflation rate and the interest rate considered in the present analysis is Fisher's original weak form which implies that markets do not suffer from money illusion but from fiscal illusion. ${ }^{26}$ Due to the complexity of the German tax system and as the influence of the tax system is not of main interest in the context of this analysis, tax on interest income is neglected here.

To check whether the long-run relationships found by the Johansen procedure are stable, the plots of the cointegrating vectors are presented in Fig. 4. Coint1 represents the long-run money demand relationship, Coint 2 is the interest rate spread and Coint 3 depicts the long-run Fisher effect. Apart from a seasonal pattern, the first and the third cointegration vector appear to be stationary from visual inspection. From the plot, the yield spread could also

\footnotetext{
26 Some studies mainly concerned with the Fisher effect have also accounted for the effects of taxes on financial returns. The tax-adjusted Fisher equation (assuming a full Fisher effect) can be represented as $r_{t}=\frac{1}{1-\tau} r_{r, t}+\frac{1}{1-\tau} \pi_{t}-\frac{1}{1-\tau} \varepsilon_{t}$, where the coefficients exceed unity since $0<\tau<1$ ( $\tau$ : tax rate). For details, see e.g. MacDonald and Murphy (1989).
} 

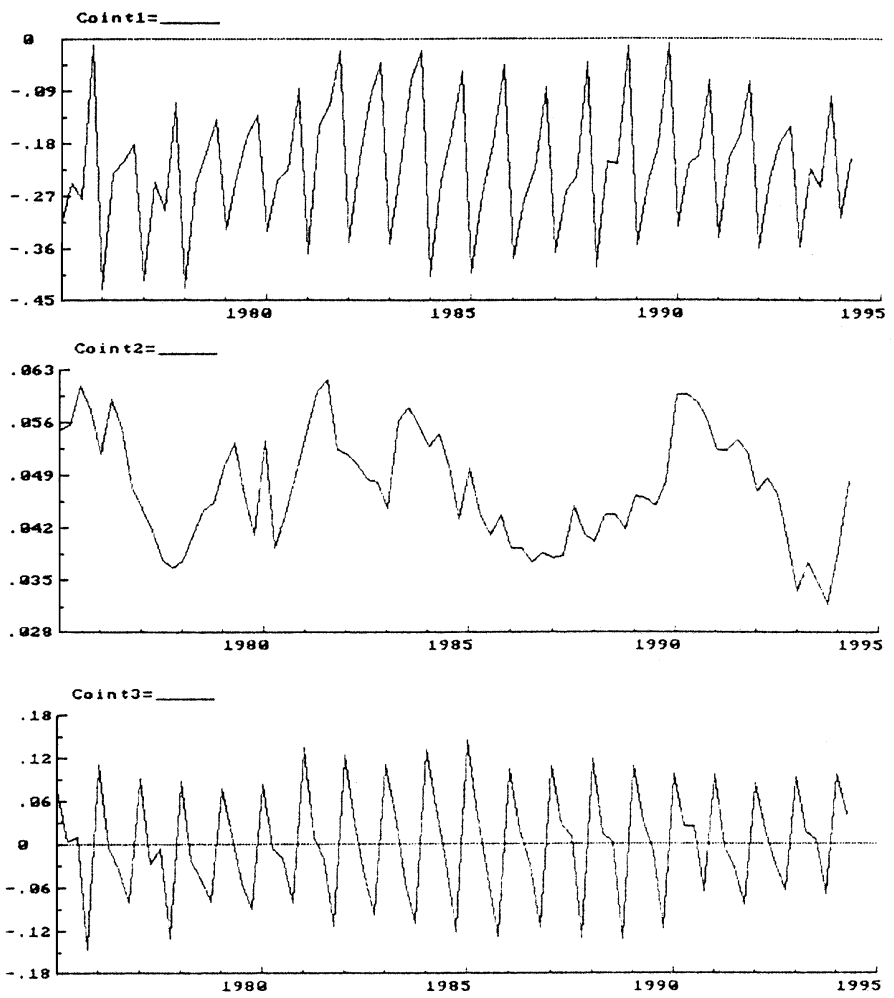

Fig. 4. Cointegrating relationships: Money demand, interest rate spread and Fisher effect

be considered as a non-stationary series, but the test results indicate quite clearly that the spread is stationary for the period considered.

In section 3.1 the initial $\operatorname{VAR}(2)$, on which the analysis is based, has been found to be stable over time. Also, the recursive eigenvalues of the VAR have been calculated. They are depicted in Fig. 5. All recursive eigenvalues are reasonably stable over time. The graphs of the first and the second recursive eigenvalues show that there are at least two cointegration vectors. The last eigenvalue is nearly zero and the fourth eigenvalue is quite small as well. The third recursive eigenvalue is double the size of the fourth recursive eigenvalue. It can also be seen from the graph, that the second and the third eigenvector are very close to each other. As the trace test clearly indicated three cointegration vectors, the existence of a third long-run relationship is supported. Thus, three stable long-run relationships between the variables considered are confirmed, i.e. a money demand relationship, the interest rate differential and a relationship reflecting the long-run Fisher effect.

\section{Concluding remarks}

In this paper, three long-run relationships influencing German monetary policy are identified within the framework of the Johansen procedure. Johansen's rank test indicates a cointegration rank of $r=3$. Weak exogeneity of the 

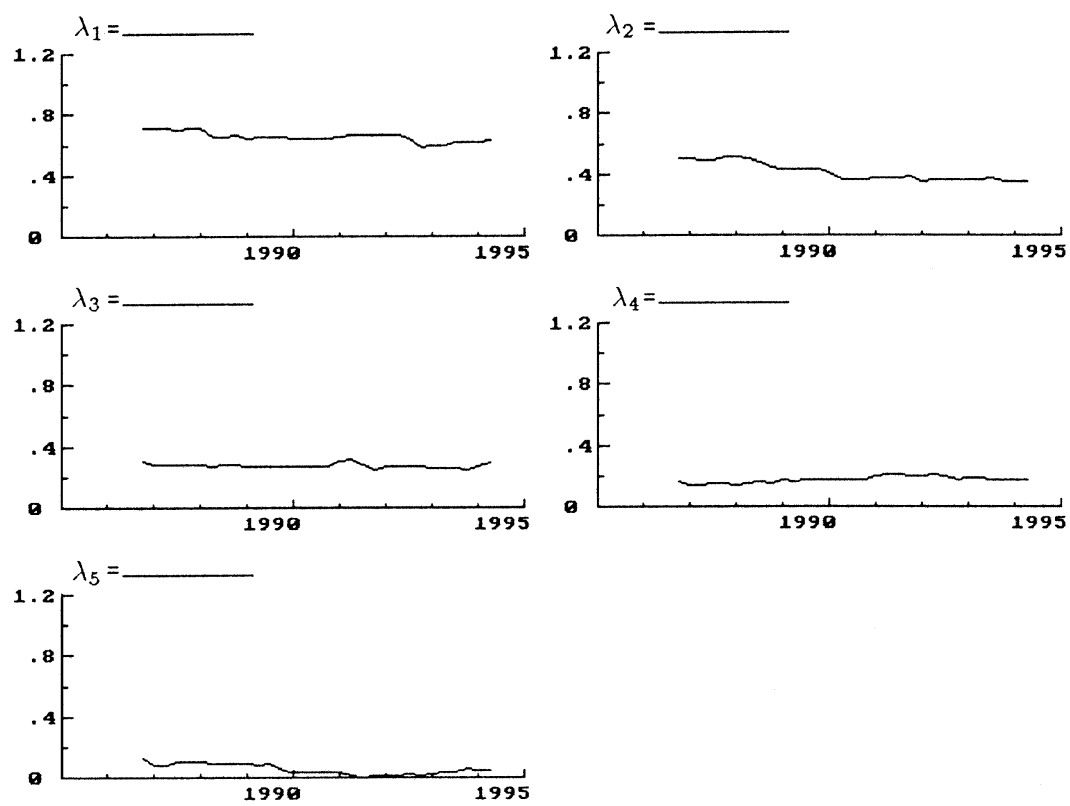

Fig. 5. Recursive eigenvalues

variables of the money demand equation is rejected by the data. Restrictions have been tested on the estimated cointegration relations using likelihood ratio tests. These tests indicate that there are three stable cointegration relationships between the variables of the money demand system: a money demand relationship, the yield spread and a Fisher equation. These relationships are found stable over the period of the EMS where the structural break of German reunification can be modelled by dummy variables and a change in the weights of the own interest rate.

The result of this analysis is remarkable as these three long-run relationships suggested by economic theory can be identified simultaneously within the system considered. The stable long-run relationships obtained in this study are of great interest in the context of German monetary policy, because the stability of the long-run money demand relationship as well as the long-run Fisher effect and the long-run relationship between short- and long-term interest rates have implications for the conduct and transmission process of monetary policy. In addition to its monetary target M3, the Bundesbank also monitors other indicators, e.g. the term structure of interest rates, to obtain information on potential inflationary risks. Therefore, one interesting result of this study is the finding of the interest rate spread to be stationary. Further, the finding that money demand in Germany is still stable after reunification (if the structural break is modelled) is an important argument for the policy of monetary targeting to be an appropriate strategy for the Bundesbank.

\section{Appendix: Data}

The nominal M3 time series and the interest rate data are obtained from the Monthly Reports of the Deutsche Bundesbank. The long-term interest rate 
is an average yield on bonds in circulation (durchschnittliche Umlaufsrendite inländischer Inhaberschuldverschreibungen) which is constructed as a weighted average of bonds in circulation. The own rate of M3 is constructed as a weighted average of the interest rate on savings deposits (Spareinlagen mit gesetzlicher Kündigungsfrist) and the interest rate on time deposits, represented by time deposits of 1 to 3 months to maturity (including deposits between 1 and 5 million DM). The GNP data are of the German Institute for Economic Research (Deutsches Institut für Wirtschaftsforschung, Berlin). The GNP data for the new and old federal German states (Bundesländer) together for the period since reunification had to be constructed as quarterly data on GNP for the reunited Germany have only recently become available. These data have been constructed using semi-annual data including the new federal states made available by the Sachverständigenrat (council of experts) (1994). The quarterly observations have been constructed for the period 1990(3) to 1994(2) on the basis of the quarterly data available for the old federal states.

\section{References}

Banerjee A, Dolado J, Galbraith J, Hendry D (1993) Co-integration, error-correction, and the econometric analysis of non-stationary data. Oxford University Press

Baumol W (1952) The transactions demand for cash: An inventory theoretic approach. Quarterly Journal of Economics 66(4):545-556

Beyer A (1994) Die Geldmenge M3 in Deutschland: Geldnachfrage und Geldmengensteuerung eine ökonomische Studie. Frankfurt Working Papers 33, Johann-Wolfgang-Goethe Universität, Frankfurt

Biefang-Frisancho Mariscal I, Trautwein H-M (1994) A cointegration and error correction model of the demand for money (M3) in Germany. In: Bol. G, Nakhaeizadeh G, Vollmer (eds.) K-H Finanzmarktanwendungen neuronaler Netze und ökonometrischer Verfahren, Vol. 93 of Wirtschaftswissenschaftliche Beiträge, Physica-Verlag, Heidelberg

Campbell J, Shiller R (1987) Cointegration and the tests of present value models. Journal of Political Economy 95:1062-1088

Campbell J, Shiller R (1991) Yield spreads and interest rate movements: A bird's eye view. Review of Economic Studies 58:495-514

Chow G (1960) Tests of equality between sets of coefficients in two linear regressions. Econometrica 28:519-605

Crowder W, Hoffman D (1996) The long-run relationship between nominal interest rates and inflation: The Fisher equation revisited. Journal of Money, Credit, and Banking 28(1):102118

Deutsche Bundesbank (1994) Das Geldmengenziel für das Jahr 1994. Monatsbericht Januar 1994, pp. $19-23$

Deutsche Bundesbank (1995a) Geldnachfrage und Währungssubstitution in Europa. Monatsbericht Januar 1995, pp. 33-49

Deutsche Bundesbank (1995b) Überprüfung der Geldmengenziele und Neuordnung der Mindestreserven. Monatsbericht Juli 1995

Doornik J, Hendry D (1994a) PcFiml 8.0, Interactive econometric modelling of dynamic systems. Thomson Publishing

Doornik J, Hendry D (1994b) PcGive 8.0, An interactive econometric modelling system. Thomson Publishing

Engle R (1982) Autoregressive conditional heteroscedasticity, with estimates of the variance of United Kingdoms inflations. Econometrica 50:987-1007

Fama E (1984) The information of the term structure. Journal of Financial Economics 13:509528

Fama E (1990) Term structure forecasts of interest rates, inflation, and real returns. Journal of Monetary Economics 25(1):59-76

Fisher I (1930) The theory of interest. Macmillan, New York 
Friedman M (1956) The quantity theory of money - A restatement. In: Friedman M (ed.) Studies in the quantity theory of money, University of Chicago Press, Chicago

Gaab W (1996) On the demand for Divisia and simple-sum M3 in Germany, 1960-93. In: Mullineux A (ed.) Financial innovation, banking and monetary aggregates. Edward Elgar, pp. $160-186$

Gaab W, Liedtke O (1992) On the long-run relationship between money, output and interest rates: A cointegration analysis for West Germany. Recherches Economiques de Louvain 58(34):455-471

Gaab W, Mullineux A (1996) Financial innovation, monetary aggregates and monetary policy in the UK and Germany. In: Duwendag D (ed.) Finanzmärkte, Finanzinnovationen und Geldpolitik. Duncker \& Humblot, pp. 73-110

Gerlach S (1995) The information content of the term structure: Evidence for Germany. Working Paper 29, BIS

Hamilton J (1994) Time series analysis. Princeton University Press, Princeton, New Jersey

Hansen G (1997) The domestic term structure and international interest linkages: A cointegration analysis. Weltwirtschaftliches Archiv 132:675-689

Hansen G, Kim J (1995) The stability of German money demand. Tests of the cointegration relation. Weltwirtschaftliches Archiv 131:286-301

Hardouvelis G (1994) The term structure spread and future changes in long and short rates in the G7 countries. Journal of Monetary Economics 33:255-283

Hargreaves C (1994) A review of methods of estimating cointegrating relationships. In: Hargreaves $\mathrm{C}$ (ed.) Nonstationary time series analysis and cointegration, Oxford University Press

Harvey A (1990) The econometric analysis of time series, 2nd edn, Philip Allan, Hemel Hempstead

Hassler U, Nautz D (1997) The link between German short- and long-term interest rates: Some evidence agianst the term structure oriented monetary policy. Jahrbücher für Nationalökonomie und Statistik, forthcoming

Haug A (1996) Tests for cointegration: A Monte Carlo comparison. Journal of Econometrics 71:89-115

Hendry D, Doornik J (1994) Modelling linear dynamic econometric systems. Scottish Journal of Political Economy 41(1):1-33

Hicks J (1939) Value and capital. Clarendon Press, Oxford

Hoffman D, Rasche R (1996) Aggregate money demand functions. Kluwer Academic Publishers, Boston

Issing O (1995) Die Geldmengenstrategie der Deutschen Bundesbank. In: Siebke J, Thieme H (eds) Geldpolitik. Zwanzing Jahre Geldmengensteuerung in Deutschland, Nomos Verlagsgesellschaft, Baden-Baden, pp. 9-34

Issing O, Tödter K-H (1995) Geldmenge und Preise im vereinten Deutschland. In: Duwendag D (ed.) Neuere Entwicklungen in der Geldtheorie und Währungspolitik, Duncker \& Humblot, Berlin, pp. 97-123

Johansen S (1988) Statistical analysis of cointegration vectors. Journal of Economic Dynamics and Control 12:231-54

Johansen S (1991) Estimation and hypothesis testing of cointegration vectors in Gaussian vector autoregressive models. Econometrica 59(6):1551-81

Johansen S (1995) Likelihood-based inference in cointegrated vector autoregressive models. Oxford University Press

Johansen S, Juselius K (1990) Maximum likelihood estimation and inference on cointegration - with applications to the demand for money. Oxford Bulletin of Economics and Statistics 52:169210

Johansen S, Juselius K (1994) Identification of the long-run and the short-run structure. An application to the ISLM model. Journal of Econometrics 63:7-36

Johansen S, Nielsen B (1993) Manual for the simulation program DisCo. Institute of Mathematical Statistics, University of Copenhagen

Juselius K (1996) The changing role of the German Bundesbank. An empirical analysis of German monetary policy before and after 1983. Oxford Bulletin of Economics and Statistics 58(4):791-819

Keynes J (1936) The general theory of employment, interest, and money. Macmillan, London and New York

Kirchgässner G, Wolters J (1990) Sind die Realzinsen stationär? Theoretische Überlegungen und empirische Ergebnisse. Kredit und Kapital 23(4):468-495 
Kole L, Meade E (1995) German monetary targeting: A retrospective view. Technical Report 10, Federal Reserve Bulletin

König R (1996) The Bundesbank's experience of monetary targeting. In: Deutsche Bundesbank (ed.) Monetary strategies in Europe, Verlag Vahlen, pp. 107-140

Kugler P (1996) Long term bond yields, monetary policy and the expectations hypothesis of the term structure of interest rates. Diskussionsschriften 96-6, Universität Bern

Laidler DE (1993) The demand for money: Theories, evidence, problems. 2nd edn, HarperCollins College Publishers, New York

Lütkepohl H (1991) Introduction to multiple time series analysis. Springer Verlag, Heidelberg

MacDonald R, Murphy P (1989) Testing for the long run relationship between nominal interest rates and inflation using cointegration techniques. Applied Economics 21:439-447

MacKinnon J (1991) Critical values for co-integration tests. In: Engle R, Granger C (eds) Longrun economic relationships, Oxford University Press, pp. 267-76

Mankiw N (1986) The term structure of interest rates revisited. Brookings Papers on Economic Activity 1:61-96

Mishkin F (1992) Is the Fisher effect for real? A reexamination of the relationship between inflation and interest rates. Journal of Monetary Economics 30:195-215

Nielsen B (1994) DisCo. Institute of Mathematical Statistics, University of Copenhagen

Perron P (1989) The great crash, the oil price shock, and the unit root hypothesis. Econometrica 57(6):1361-1401

Pfann G, Schotman P, Tschernig R (1995) Nonlinear interest rate dynamics and implications for the term structure. Journal of Econometrics 74:149-176

Phillips P, Hansen B (1990) Statistical inference in instrumental variables regression with I(1) processes. Review of Economic Studies 57:99-125

Reimers H (1992) Comparisons of tests for multivariate cointegration. Statistical Papers 33:335-359

Scharnagl M (1996) Geldmengenaggregate unter Berücksichtigung struktureller Veränderungen an den Finanzmärkten. Diskussionspapier 2/96, Deutsche Bundesbank

Schich S (1996) Alternative Spezifikationen der deutschen Zinsstrukturkurve und ihr Informationsgehalt hinsichtlich der Inflation. Diskussionspapier 8, Deutsche Bundesbank

Shiller R (1990) The term structure of interest rates. In: Friedman B, Hahn F (eds) Handbook of monetary economics, Elsevier Science Publisher

Tobin $\mathbf{J}$ (1956) The interest elasticity of transactions demand for cash. Review of Economics and Statistics 38(3):241-247

Tobin J (1958) Liquidity preference as behavior towards risk. Review of Economic Studies 25(February):65-86

Toda H (1994) Finite sample properties of likelihood ratio tests for cointegrating ranks when linear trends are present. Review of Economics and Statistics 76:66-79

Toda H (1995) Finite sample performance of likelihood ratio tests for cointegrating ranks in vector autoregressions. Econometric Theory 11:1015-1032

Tödter K-H (1994) Eine transaktionsorientierte Geldmenge. Kredit und Kapital 27:319-347

Tullio G, de Souza E, Giucca P (1996) The demand for money functions in Europe and in Germany before and after the fall of the Berlin wall. In: de Grauwe P, Micossi S, Tullio G (eds) Inflation and wage behaviour in Europe, Clarendon Press, Oxford, pp. 310-338

Tzavalis E, Wickens M (1996) Forecasting inflation from the term structure. Journal of Empirical Finance 3:103-122

von Hagen J, Neumann M (1988) Instability versus dynamics: A study in West German demand for money. Journal of Macroeconomics 10(3):327-349

Wallace M, Warner J (1993) The Fisher effect and the term structure of interest rates: Tests of cointegration. The Review of Economics and Statistics-Notes 75(2):320-324

Wolters J (1995) On the term structure of interest rates - empirical results for Germany. Statistical Papers 36:193-214

Wolters J (1997) Untersuchung der Renditestruktur am deutschen Kapitalmarkt, 1970-1996. Diskussionsbeiträge 7, Freie Universität Berlin

Wolters J, Lütkepohl H (1997) Die Geldnachfrage für M3: Neue Ergebnisse für das vereinigte Deutschland. Ifo-Studien 43:35-54

Wolters J, Teräsvirta T, Lütkepohl H (1996) Modelling the demand for M3 in the unified Germany. Discussion Paper 24, Sonderforschungsbereich 373, Humboldt-Universität zu Berlin

Yuhn K-H (1996) Is the Fisher effect robust? Further evidence. Applied Economics Letters 3:4144 